\title{
Synthesis, Characterization and Analytical Applications of Antimony(III) molybdoarsenate as a Cation Exchanger and Selective for $\mathrm{Pb}$ (II) and $\mathrm{Cu}(\mathrm{II})$ lons
}

\author{
TEENA $^{1 *}$, VANDANA SHARMA ${ }^{2}$, KOSHAL K.T. $^{3}$ and VIRENDRA KUMAR \\ 'Department of Chemistry, Chaudhary Charan Singh University, (U.P 250004), Meerut, India. \\ ${ }^{2}$ Department of Environmental Sciences, Deen Dayal Upadhaya College, \\ University of Delhi (110078), India. \\ ${ }^{3}$ Department of Chemistry, Meerut College, Meerut, (U.P 250004), India. \\ ${ }^{4}$ Department of Chemistry, University of Allahabad, Allahabad, (U.P 211002), India. \\ *Corresponding author E-mail: teenaprakash15@gmail.com \\ http://dx.doi.org/10.13005/ojc/330219
}

(Received: March 18, 2017; Accepted: March 23, 2017)

\begin{abstract}
These three component inorganic ion-exchanger was synthesized under different condition. The most thermal and chemical properties of this material is prepared by intermixing solutions of sodium molybdate $(0.1 \mathrm{M})$, sodium arsenate $(0.1 \mathrm{M})$ and antimony $(\mathrm{III})$ chloride $(0.1 \mathrm{M})$ solution in different volume ratios at $\mathrm{pH}-1$. The lon-exchange capacity of all the samples was determined by column process. The selected sample was synthesized in bulk for detailed studies. Its ion-exchange capacity of synthesized material for $\mathrm{Na}^{+}$has been found to be $2.30 \mathrm{meq} / \mathrm{g}$. Characterization of the prepared material was done by different parameters like FTIR, TGA curve, X-ray diffraction, and other studies include $\mathrm{pH}$ titration, Kd values, thermal \& chemical stabilities. The synthesized ionexchanger has been demonstrated by achieved binary and water softening separations for different analytical practical uses.
\end{abstract}

Keywords: Cation-exchanger, $\mathrm{pH}$ titration, Distribution studies, Thermal and chemical stabilities,

Binary separation, Hardness of water.

\section{INTRODUCTION}

lon-exchange may be defined as reversible interchange of ions takes place between two phases is solid and liquid ${ }^{1}$. Ion-exchange technology is most important versatile technology in the field of separation science. These techniques can be applied to both macro as well as micro analysis for the routine separation. Thus separation is a important part of chemical analysis². Mostly synthetic ionexchangers were inorganic materials. These were the synthetic zealites or permutites which were developed by Grans, and other workers for use in water softening process ${ }^{3}$.In recent years, various zeolites with completely regular crystal structure have been synthesized like zeolite $A^{4}$. 
Inorganic cation-exchanger have drawn the attention to their selectivity, temperature, thermal and chemical stabilities ${ }^{5}$. Synthesized a two component ion-exchanger antimony(III) silicate of the class of multivalent metal acid salt and its ion-exchange behaviour towards alkali and alkaline earth metal ions was determined by the column technique ${ }^{6}$. Similarly a large number of three component ion-exchangers like antimony(III) iodostannate ${ }^{7}$, titanium(IV) tungstoarsenate $^{8}$, stannic(IV) molybdophosphate ${ }^{9}$ and zirconium(IV) selenomolybdate ${ }^{10}$, cerium(IV) iodotungstate ${ }^{11}$, iron(III) tungstomolybdate ${ }^{12}$

In the present work is concerned with the new synthesized and characterized three component ion-exchanger. The ion-exchange capacity was determined by using column and $\mathrm{pH}$ titration method. Further characterization of the exchanger was done by chemical and thermal stabilities, FTIR, X-ray, and $\mathrm{Kd}$ values. The newly synthesized ion-exchanger

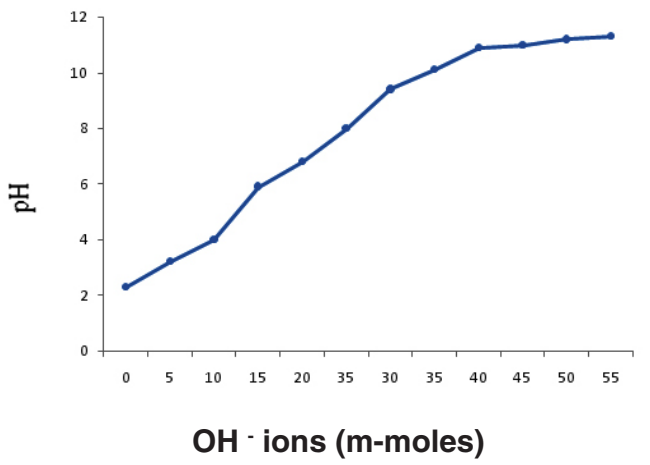

Fig. 1: pH titration curve of antimony(III) molybdoarsenate

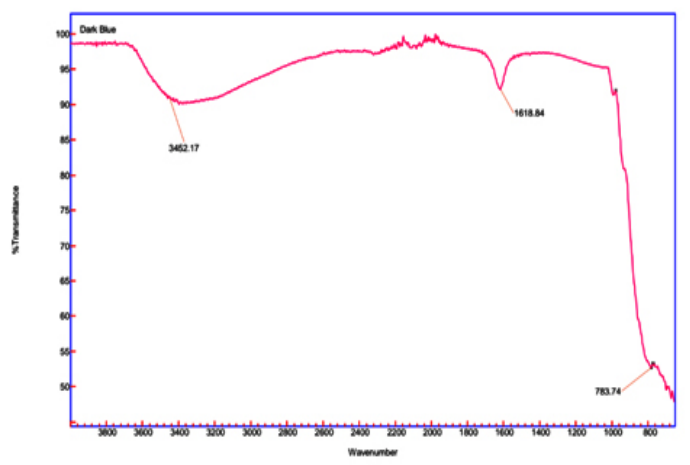

Fig. 2: IR spectrum of antimony(III) molybdoarsenate is found to be possess extensive application in analytical and industrial chemistry. The important applications achieved with the help of antimony(III) molybdoarsenate are binary separation.

\section{EXPERIMENTAL}

\section{Materials and Instrumentation}

All chemicals and reagents were used for prepared material. A Digital Toshniwal pH Meter was used for $\mathrm{pH}$ measurement. Thermal and equilibrium studies were performed with the help of Tanco's Electric Rotary Shaker respectively. Samson S-300 D Electronic Balance was used for weighing. Philips Analytical X-ray B.V. Diffractometer and Cary Aglient 630 (ATR module) IR Spectrophotometer were used for XRD and FTIR respectively. All glass wares of borosil make are used throughout experiment research work.

\section{Preparation of Ion-Exchanger Material}

Three component ion-exchanger was prepared by mixing $0.1 \mathrm{M}$ antimony(III) chloride aqueous solution gradually to adding an aqueous solution of sodium molybdate $(0.1 \mathrm{M})$ and sodium arsenate $(0.1 \mathrm{M})$ in different volume ratios to get various samples. The $\mathrm{pH}$ of resulting precipitates was maintained at 1.0 with the help of dil hydrocloric acid and allowed to stand for twenty four hours at room temperature. The precipitates was filtered, and washed with demineralized water. The material was dried at $40 \pm 1^{\circ} \mathrm{C}$ in an oven. The dried material was broken into small granules by placing in demineralized water. The granules were converted into hydrogen form by keeping with $\mathrm{M} \mathrm{HNO}_{3}$ solution for twenty four hours at room temperature. The material was then washed with demineralized water to remove the excess acid and finally material dried at $40 \pm 1^{\circ} \mathrm{C}$ in an electric oven. Prepared material are known as an exchanger. The results are shown in Table 1.

\section{CHARACTERIZATION} Ion-Exchange Capacity

IEC of the different samples was determined by column, taken $0.50 \mathrm{~g}$ of the material in $\mathrm{H}^{+}$form in a each column having glass wool support and washed them, with demineralized water. A molar solution of sodium nitrate was passed through the each column maintaining the flow rate at 8-10 
drops/min. The effluents were carefully collected in $250 \mathrm{ml}$ conical flask separately in each case. The $\mathrm{H}^{+}$ ions eluted from the material through column were titrimetrically determined with the help of standard $\mathrm{NaOH}$ solution.

The ion-exchange capacity of the material was also determined by monovalent and bivalent, alkali and alkaline earth metals as represented by Table 2.

\section{pH Titration}

$\mathrm{pH}$ titration was performed by the batch method using the method of, Topp and Pepper ${ }^{13}$. In this method the $\mathrm{pH}$ titration of the exchanger in $\mathrm{H}^{+}$ form was performed in $\mathrm{NaCl}-\mathrm{NaOH}$ system. Eleven equal amount of $0.50 \mathrm{~g}$ it the exchanger in each were placed in eleven $250 \mathrm{ml}$ conical flasks separately by the addition of equimolar solutions of $\mathrm{NaCl}$ and $\mathrm{NaOH}$ in different volume ratios, the final volume of the solution was kept $50 \mathrm{ml}$ so as to maintain the ionic strength constant. Then the intermittent shaking of the mixture was kept at room temperature. The $\mathrm{pH}$ titration curve of the exchanger is shown in Figure1.

\section{Thermal Stability}

To determine the thermal stability of the exchanger was evaluated by heating it at different temperatures upto $700^{\circ} \mathrm{C}$ in a muffle furnace for one hour, and then cooled to room temperature in a desiccators. The loss of weight and change in colour of the ion-exchanger was observed in each case and ion-exchange capacity was determined by column method. The results are given in Table 3.

\section{Chemical Analysis}

To examine the chemical stability of the exchanger was assessed in different mineral acids such as $\mathrm{H}_{2} \mathrm{SO}_{4}, \mathrm{HNO}_{3}$ and $\mathrm{HCl}$ bases such as $\mathrm{KOH}$ and $\mathrm{NaOH}$, organic acids such as $\mathrm{CH}_{3} \mathrm{COOH}$, $\mathrm{HCOOH}, 0.50 \mathrm{~g}$ of the exchanger was taken in 50

Table 1: Synthesis of antimony(III) molybdoarsenate

\begin{tabular}{|c|c|c|c|c|c|c|c|}
\hline \multirow[t]{2}{*}{ SI.No. } & \multicolumn{3}{|c|}{ Molar Conc. (M) } & \multirow{2}{*}{$\begin{array}{l}\text { Mixing } \\
\text { Ratios }\end{array}$} & \multirow[t]{2}{*}{$\mathrm{pH}$} & \multirow{2}{*}{$\begin{array}{c}\text { Appearance of } \\
\text { Precipitate }\end{array}$} & \multirow{2}{*}{$\begin{array}{c}\text { IEC } \\
(\mathrm{meq} / \mathrm{g})\end{array}$} \\
\hline & $\mathrm{Sb}^{3+}$ & $\mathrm{MoO}_{4}{ }^{2-}$ & $\mathrm{AsO}_{3}{ }^{2-}$ & & & & \\
\hline 1 & 0.1 & 0.1 & 0.1 & $1: 1: 1$ & 1 & Mid cream ppt. & 0.48 \\
\hline 2 & 0.1 & 0.1 & 0.1 & $1: 2: 2$ & 1 & Mid cream ppt. & 0.98 \\
\hline 3 & 0.1 & 0.1 & 0.1 & $1: 2: 1$ & 1 & Sky blue ppt. & 1.69 \\
\hline 4 & 0.1 & 0.1 & 0.1 & $2: 1: 1$ & 1 & Sky blue ppt. & 1.89 \\
\hline 5 & 0.1 & 0.1 & 0.1 & 2:2:1 & 1 & Sky blue ppt. & 1.99 \\
\hline 6 & 0.1 & 0.1 & 0.1 & $1: 1: 3$ & 1 & Dark blue ppt. & 1.12 \\
\hline 7 & 0.1 & 0.1 & 0.1 & $1: 3: 1$ & 1 & Light blue ppt. & 0.79 \\
\hline 8 & 0.1 & 0.1 & 0.1 & 3:1:1 & 1 & Light yellow ppt. & 1.02 \\
\hline 9 & 0.1 & 0.1 & 0.1 & $2: 1: 3$ & 1 & Dark blue ppt. & 2.30 \\
\hline 10 & 0.1 & 0.1 & 0.1 & 3:2:1 & 1 & Light yellow ppt. & 1.12 \\
\hline
\end{tabular}

Table 2: lon-exchange capacity of antimony(III) molybdoarsenate for different metal cations

\begin{tabular}{lccccc}
\hline SI. No. & Cation & $\begin{array}{c}\text { Salt } \\
\text { Used }\end{array}$ & $\begin{array}{c}\text { Concentration of } \\
\text { Salt Used }\end{array}$ & $\begin{array}{c}\text { I.E.C. } \\
(\mathbf{m e q} / \mathbf{g})\end{array}$ & $\begin{array}{c}\text { Hydrated lonic } \\
\text { Radii }\left(\mathbf{A}^{\mathbf{0}}\right)\end{array}$ \\
\hline & & & & & \\
1 & $\mathrm{Li}^{+}$ & $\mathrm{LiCl}$ & $0.1 \mathrm{M}$ & 2.10 & 10.0 \\
2 & $\mathrm{Na}^{+}$ & $\mathrm{NaCl}$ & $0.1 \mathrm{M}$ & 2.30 & 7.9 \\
3 & $\mathrm{~K}^{+}$ & $\mathrm{KBr}$ & $0.1 \mathrm{M}$ & 2.47 & 5.3 \\
4 & $\mathrm{Mg}^{2+}$ & $\mathrm{MgCl}_{2}$ & $0.1 \mathrm{M}$ & 1.76 & 10.80 \\
5 & $\mathrm{Ca}^{2+}$ & $\mathrm{CaCl}_{2}$ & $0.1 \mathrm{M}$ & 1.89 & 9.60 \\
6 & $\mathrm{Ba}^{2+}$ & $\mathrm{BaCl}_{2}$ & $0.1 \mathrm{M}$ & 2.05 & 8.80 \\
\hline
\end{tabular}


$\mathrm{ml}$ of several molar solutions and kept for twenty four hours at room temperature and then filtered and finally dried at $40 \pm 1^{\circ} \mathrm{C}$ in an oven. Now the dry material loss of weight of all samples was observed and ion-exchange capacities were determined by column method as represented in Table 4.

\section{Distribution Studies}

Distribution coefficient for several metal ions in demineralized water was carried out by the batch process ${ }^{14}$. In this process, $0.50 \mathrm{~g}$ portion of the exchanger in $\mathrm{H}^{+}$form was equilibrated with $25 \mathrm{ml}$ of $0.1 \mathrm{M}$ solutions of different metal ions. The mixture was shaken for three hours with the help of rotary shaker and then to attain complete equilibrium. The determination of metal ions present in the solution was titrated against the standard solution of EDTA. $\mathrm{Kd}$ values were calculated using the formula

$$
K d=\frac{I-F}{F} X \frac{V}{W}
$$

Where $\mathrm{I}$ is the intial volume of EDTA solution, $F$ is the final volume of EDTA solution after equilibrated, $\mathrm{V}$ is the volume of the metal ion solution $(\mathrm{ml})$ and $\mathrm{W}$ is the weight of the ion-exchanger in gram $^{15}$. The results are summarized in Table 5.

\section{FTIR and X-ray Diffraction}

IR studies of the material were recorded between $3800 \mathrm{~cm}^{-1}$ and $800 \mathrm{~cm}^{-1}$. The spectrum shows a broad bands in the $3452.17 \mathrm{~cm}^{-1}$ region, characteristics of the $\mathrm{O}-\mathrm{H}$ stretching and bending mode. Finally the spectrum also shows strong and weaks bands at $1618.84 \mathrm{~cm}^{-1}$ and $783.74 \mathrm{~cm}^{-1}$, respectively which indicates the presence of arsenate and molybdate. The band at $783.74 \mathrm{~cm}^{-1}$ shows the presence of metal oxide bond. The spectrum are shown in Figure 2. The X-ray diffraction pattern of the exchanger are given in Figure3. Data shows a amorphous nature with weak peaks.

\section{TGA Curve}

The themogram of antimony(III) molybdoarsenate in $\mathrm{H}^{+}$form was get it done at Instrumentation centre, IIT Roorkee at a rate of $10^{\circ} \mathrm{C} /$ min. in nitrogen atmosphere from room temperature. The results are shown in Figure 4.

\section{Separations Achieved}

The values of separation factor for different metal ions pairs obtained antimony(III) molybdoarsenate were greater than three and their values are given in Table 6.

\section{Binary Separation of Metal lons}

The separation factors are the guiding measure for the separation. Binary separation of metal ions were achieved are given in Table 7. For binary separations, $0.50 \mathrm{~g}$ of the exchanger in $\mathrm{H}^{+}$ form was packed in glass column. The column was washed with demineralized water and then metal ion mixture was poured in column separately. The absorbed metal ions were eluted with appropriate eluents one by one. The flow rate of the effluent was maintained at $1 \mathrm{ml} / \mathrm{min}$ throught the elution process ${ }^{16}$. The effluents were collected separately conical flask and metal ion concentration were determined (Complexometric Titration) against disodium EDTA salt solution using suitable indicators.

Table 3: Thermal stability of antimony(III) molybdoarsenate

\begin{tabular}{ccccc}
\hline SI.No. & $\begin{array}{c}\text { Drying } \\
\text { Temperature } \\
\left({ }^{\circ} \mathbf{C}\right)\end{array}$ & $\begin{array}{c}\text { Weight of lon- } \\
\text { Exchanger } \\
\text { Before Heating } \\
\mathbf{( g )}\end{array}$ & $\begin{array}{c}\text { Change in } \\
\text { Colour }\end{array}$ & $\begin{array}{c}\text { IEC } \\
(\mathbf{m e q} / \mathbf{g})\end{array}$ \\
\hline 1 & $100^{\circ} \mathrm{C}$ & 0.50 & Dark blue & 1.90 \\
2 & $200^{\circ} \mathrm{C}$ & 0.50 & Dark blue & 1.20 \\
3 & $300^{\circ} \mathrm{C}$ & 0.50 & Light grey & 0.81 \\
4 & $400^{\circ} \mathrm{C}$ & 0.50 & Dark grey & 0.41 \\
5 & $500^{\circ} \mathrm{C}$ & 0.50 & Dusky black & 0.22 \\
6 & $600^{\circ} \mathrm{C}$ & 0.50 & Black & 0.10 \\
7 & $700^{\circ} \mathrm{C}$ & 0.50 & Black & - \\
\hline
\end{tabular}




\section{Water Softening}

Hardness causing $\mathrm{Ca}^{2+}$ and $\mathrm{Mg}^{2+}$ were also removed with help of the synthesized ionexchanger. Column method was used for the removal of ions. The hardness of the water samples was determined by complexometric titration method in which, Erichrome Black-T was used as an indicator. Hardness causing $\mathrm{Ca}^{2+}$ and $\mathrm{Mg}^{2+}$ loaded in the column were eluted using $0.01 \mathrm{M} \mathrm{HClO}_{4}$ and $1.0 \mathrm{M} \mathrm{HNO}_{3}$ as eluents respectively. The results are summerised in Table 8.

Table 4: Chemical stability of antimony(III) molybdoarsenate

\begin{tabular}{|c|c|c|c|}
\hline SI.No. & Solution & $\begin{array}{c}\text { Percentage } \\
\text { Weight } \\
\text { Loss }\end{array}$ & $\begin{array}{c}\text { Ion- } \\
\text { Exchange } \\
\text { Capacity }\end{array}$ \\
\hline 1 & $1 \mathrm{M} \mathrm{HCl}$ & 2 & 1.50 \\
\hline 2 & $2 \mathrm{M} \mathrm{HCl}$ & 4 & 1.01 \\
\hline 3 & $1 \mathrm{M} \mathrm{HNO}_{3}$ & 0 & 2.30 \\
\hline 4 & $2 \mathrm{M} \mathrm{HNO}_{3}$ & 0 & 2.28 \\
\hline 5 & $1 \mathrm{M} \mathrm{H}_{2} \mathrm{SO}_{4}$ & 6 & 1.00 \\
\hline 6 & $2 \mathrm{M} \mathrm{H}_{2} \mathrm{SO}_{4}$ & 12 & 0.55 \\
\hline 7 & $1 \mathrm{M} \mathrm{CH}_{3} \mathrm{COOH}$ & 6 & 1.10 \\
\hline 8 & $2 \mathrm{M} \mathrm{CH}_{3} \mathrm{COOH}$ & 12 & 0.72 \\
\hline 9 & $1 \mathrm{M} \mathrm{HCOOH}$ & 8 & 0.51 \\
\hline 10 & $2 \mathrm{M} \mathrm{HCOOH}$ & 16 & 0.26 \\
\hline 11 & $2 \mathrm{M} \mathrm{KOH}$ & $\begin{array}{c}\text { Completely } \\
\text { Dissolve }\end{array}$ & - \\
\hline 12 & $2 \mathrm{M} \mathrm{NaOH}$ & $\begin{array}{l}\text { Completely } \\
\text { Dissolve }\end{array}$ & - \\
\hline
\end{tabular}

Table 5: Distribution coefficient studies of antimony(III) molybdoarsenate

\begin{tabular}{llcc}
\hline SI.No. & $\begin{array}{c}\text { Metal } \\
\text { lons }\end{array}$ & Form & $\begin{array}{c}\text { Kd } \\
\left(\mathbf{m l g}^{-1}\right)\end{array}$ \\
\hline 1 & $\mathrm{Mg}(\mathrm{II})$ & Acetate & 9.98 \\
2 & $\mathrm{Ca}(\mathrm{II})$ & Carbonate & 10.24 \\
3 & $\mathrm{Mn}(\mathrm{II})$ & Acetate & 7.90 \\
4 & $\mathrm{Zn}(\mathrm{II})$ & Acetate & 7.79 \\
5 & $\mathrm{Co}(\mathrm{II})$ & Acetate & 7.12 \\
6 & $\mathrm{Cu}(\mathrm{II})$ & Acetate & 12.42 \\
7 & $\mathrm{Cd}(\mathrm{II})$ & Chloride & 7.89 \\
8 & $\mathrm{Ni}(\mathrm{II})$ & sulphate & 32.14 \\
9 & $\mathrm{~Pb}(\mathrm{II})$ & Nitrate & 11.20 \\
10 & $\mathrm{Bi}(\mathrm{III})$ & Nitrate & 7.03
\end{tabular}

\section{RESULTS AND DISCUSSIONS}

Different samples of the material in various volume ratios have been synthesized (shown in Table 1). One of the sample was selected for detailed studies. The high ion -exchange capacities for mono and divalent metal ions are shown in Table 2. It is evident that the affinity sequence for monvalent metal ions is $\mathrm{K}^{+}>\mathrm{Na}^{+}>\mathrm{Li}^{+}$and for divalent ions is $\mathrm{Ba}^{2+}>\mathrm{Ca}^{2+}>\mathrm{Mg}^{2+}$. The effect of charge and size of the ion on the ion-exchange capacities show that exchanging ion takes place in the hydrated form. The metal ions with smaller hydrated radii easily enter the pores of exchanger, resulting in higher adsorption ${ }^{17}$. The $\mathrm{pH}$ titration curve was carried out under equilibrium stage for $\mathrm{NaCl}-\mathrm{NaOH}$ system. The curve was plotted between $\mathrm{pH}$ values and $\mathrm{OH}^{-}$ions concentration. The results are shown in Figure 1.

The heating effect on the weight and ion-exchange capacity at various temperatures upto $700^{\circ} \mathrm{C}$ was carried out. Data shows that the ion-exchange capacity decrease with increase in temperature (Table 3). Antimony(III) molybdoarsenate are less stable in lower concentration of $\mathrm{HCl}, \mathrm{H}_{2} \mathrm{SO}_{4}$ and $\mathrm{CH}_{3} \mathrm{COOH}, \mathrm{HCOOH}$. The ion-exchanger was completely dissolve in $2 \mathrm{M} \mathrm{KOH}$ and $2 \mathrm{M} \mathrm{NaOH}$ solution (Table 4).

IR spectrum was performed at room temperature used by $\mathrm{KBr}$ disc method. The results are shown in Figure 2.

X-ray diffraction pattern of antimony(III) molybdoarsenate is amorphous nature, which indicate weak peaks with sharp intensities (Figure 3). Thermogram of prepared material recorded in Figure 4. The water molecule are lost upto $100^{\circ} \mathrm{C}(4.6 \%)$ as indicated by the first peak of the curve. Further loss in weight is observed from $400^{\circ} \mathrm{C}$ to $500^{\circ} \mathrm{C}$ and the corresponding weight loss in $24.6 \%$. From $500^{\circ} \mathrm{C}$ to $900^{\circ} \mathrm{C}$, the loss is very slow. i.e. $13.7 \%$ at $600^{\circ} \mathrm{C}, 13.6 \%$ at $700^{\circ} \mathrm{C}, 17.5 \%$ at $800^{\circ} \mathrm{C} \& 27.5 \%$ at $900^{\circ} \mathrm{C}$. At $1008^{\circ} \mathrm{C}$ a rapid decline in weight $(51.5 \%)$ is noticed.

Distribution behaviour indicate that the exchanger is selective for $\mathrm{Ni}(\mathrm{II}), \mathrm{Cu}(\mathrm{II}), \mathrm{Pb}(\mathrm{II})$, $\mathrm{Ca}(\mathrm{II})$, in compare to another metal ions. Solvent are used in binary separation and water softening 
$0.1 \mathrm{M} \mathrm{HNO}_{3}, 0.1 \mathrm{M} \mathrm{HNO}_{3}, 0.1 \mathrm{M} \mathrm{H}_{3} \mathrm{PO}_{4}, 1 \mathrm{M} \mathrm{HClO}_{4}$, $0.1 \mathrm{M} \mathrm{HNO}_{3}+0.1 \mathrm{M} \mathrm{NH}_{4} \mathrm{NO}_{3}$ it can be used for the quantitative analysis trace metal ion in environmental purpose. The results are shown in Table 7. Binary separation of $\mathrm{Ni}-\mathrm{Cd}$, amounts found of nickel and cadmium shows that almost all the nickel metal are eluted while $100 \%$ of cadmium ions are eluted showing the percentage error of $0.06 \%$. Similarly $\mathrm{Ni}-\mathrm{Pb}, \mathrm{Ni}-\mathrm{Mn}$ and $\mathrm{Ni}-\mathrm{Mg}$ pairs separation results are satisfactory as nickel is removed $95-100 \%$. These results can be compared with the previously reported binary separation results. Ni-Mg separation achieved with the help of stannic(IV) antimonate ${ }^{18}$ and tin(IV) tungstate ${ }^{19}$. The recovery ranged from $98-100 \%$ with

Table 6: Separation factor of antimony(III) molybdoarsenate

\begin{tabular}{|c|c|c|c|}
\hline SI. No. & $\begin{array}{r}\text { Separation } \\
\text { Factor }\end{array}$ & $\overline{\alpha_{B}^{A}=\frac{\text { Kd value of } A}{\text { Kd value of } B}}$ & $\begin{array}{r}\text { Value of } \\
\text { Separation } \\
\text { Factor } \\
\end{array}$ \\
\hline 1 & $\alpha_{C d}^{N i}$ & $32.14 / 7.89$ & 4.073 \\
\hline 2 & $\alpha_{P b}^{N i}$ & $32.14 / 11.20$ & 2.869 \\
\hline 3 & $\overline{\alpha_{M n}^{N i}}$ & $32.14 / 7.90$ & 4.068 \\
\hline 4 & $\alpha_{M g}^{N i}$ & $32.14 / 9.98$ & 3.220 \\
\hline
\end{tabular}

Table 7: Binary separation achieved with the help of antimony(III) molybdoarsenate

\begin{tabular}{|c|c|c|c|c|c|c|c|}
\hline SI. No. & $\begin{array}{l}\text { Metal } \\
\text { Ion Pair }\end{array}$ & $\begin{array}{c}\text { Amount } \\
\text { Loaded } \\
(\mu \mathrm{g})\end{array}$ & $\begin{array}{c}\text { Amount } \\
\text { Found } \\
(\mu g)\end{array}$ & $\begin{array}{c}\% \text { Metal } \\
\text { Ion } \\
\text { Eluted }\end{array}$ & \% Error & $\begin{array}{c}\text { Total } \\
\text { Eution } \\
\text { Volume }\end{array}$ & Eluent Used \\
\hline 1 & $\begin{array}{l}\mathrm{Ni}(\mathrm{II}) \\
\mathrm{Cd}(\mathrm{II})\end{array}$ & $\begin{array}{l}9390 \\
1624\end{array}$ & $\begin{array}{l}9180 \\
1625\end{array}$ & $\begin{array}{l}97.76 \\
100.06\end{array}$ & $\begin{array}{l}-2.24 \\
0.06\end{array}$ & $\begin{array}{l}40 \mathrm{ml} \\
50 \mathrm{ml}\end{array}$ & $\begin{array}{r}0.001 \mathrm{M} \mathrm{HNO}_{3} \\
0.1 \mathrm{M} \mathrm{HNO}_{3}+0.5 \mathrm{M} \\
\mathrm{NH}_{4} \mathrm{OH}\end{array}$ \\
\hline 2 & $\begin{array}{l}\mathrm{Ni}(I I) \\
\mathrm{Pb}(\mathrm{II})\end{array}$ & $\begin{array}{l}9390 \\
2239\end{array}$ & $\begin{array}{r}9390 \\
1920\end{array}$ & $\begin{array}{l}95.95 \\
85.75\end{array}$ & $\begin{array}{l}-5.15 \\
-5.25\end{array}$ & $\begin{array}{l}50 \mathrm{ml} \\
40 \mathrm{ml}\end{array}$ & $\begin{array}{l}0.1 \mathrm{M} \mathrm{HClO}_{4} \\
0.1 \mathrm{M} \mathrm{HNO}_{3}\end{array}$ \\
\hline 3 & $\begin{array}{l}\mathrm{Ni}(I I) \\
\mathrm{Mn}(\mathrm{II})\end{array}$ & $\begin{array}{l}9390 \\
1337\end{array}$ & $\begin{array}{l}8990 \\
1223\end{array}$ & $\begin{array}{l}95.74 \\
91.47\end{array}$ & $\begin{array}{l}-5.26 \\
-9.53\end{array}$ & $\begin{array}{l}50 \mathrm{ml} \\
30 \mathrm{ml}\end{array}$ & $\begin{array}{c}1 \mathrm{M} \mathrm{NH}_{4} \mathrm{Cl}+0.1 \mathrm{M} \\
\mathrm{HCl} \\
0.1 \mathrm{M} \mathrm{HCl}\end{array}$ \\
\hline 4 & $\begin{array}{l}\mathrm{Ni}(\mathrm{II}) \\
\mathrm{Mg}(\mathrm{II})\end{array}$ & $\begin{array}{l}9390 \\
4861\end{array}$ & $\begin{array}{l}9460 \\
4770\end{array}$ & $\begin{array}{l}100.75 \\
98.12\end{array}$ & $\begin{array}{l}0.75 \\
-2.88\end{array}$ & $\begin{array}{l}80 \mathrm{ml} \\
70 \mathrm{ml}\end{array}$ & $\begin{array}{c}1.0 \mathrm{M} \mathrm{HNO}_{3} \\
0.4 \mathrm{M} \mathrm{NH}_{4} \mathrm{NO}_{3}\end{array}$ \\
\hline
\end{tabular}

Table 8: Removal of $\mathrm{Ca}^{2+}$ and $\mathrm{Mg}^{2+}$ with the help of antimony(III) molybdoarsenate

\begin{tabular}{cccccccc}
\hline SI.No. & $\begin{array}{c}\text { Metal } \\
\text { Ion Pair }\end{array}$ & $\begin{array}{c}\text { Amount } \\
\text { Loaded } \\
(\boldsymbol{\mu g})\end{array}$ & $\begin{array}{c}\text { Amount } \\
\text { Found } \\
(\boldsymbol{\mu g})\end{array}$ & $\begin{array}{c}\text { \% Metal } \\
\text { lon Eluted }\end{array}$ & \% Error & $\begin{array}{c}\text { Total } \\
\text { Eution } \\
\text { Volume }\end{array}$ & Eluent Used \\
\hline & & & & & & & \\
2 & $\mathrm{Mg}^{2+}$ & 4861 & 4800 & 98.74 & -2.26 & $50 \mathrm{ml}$ & $1.0 \mathrm{M} \mathrm{HNO}_{3}$ \\
2 & $\mathrm{Ca}^{2+}$ & 5743 & 5741 & 99.96 & -1.04 & $50 \mathrm{ml}$ & $0.01 \mathrm{M} \mathrm{HClO}_{4}$ \\
\hline
\end{tabular}




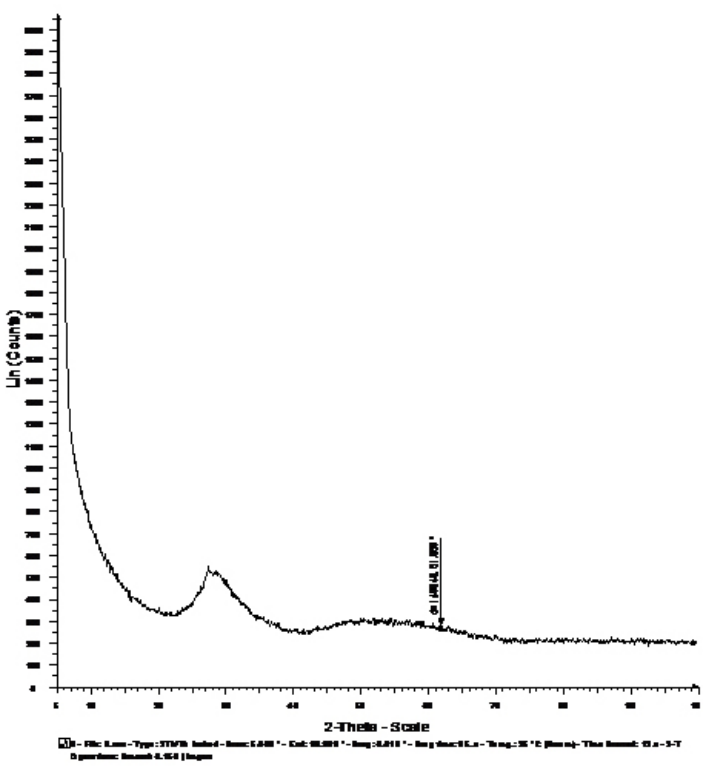

Fig. 3: XRD of antimony(III) molybdoarsenate

variation of $2 \%$ for repetitive determinations.

Water softening results obtained for antimony(III) molybdoarsenate revealed that the $\mathrm{Ca}^{2+}$ and $\mathrm{Mg}^{2+}$ can be removed to a great extent i.e. $99 \%$ and $98.74 \%$ respectively with the help of these exchanger. The results are shown in Table 8.

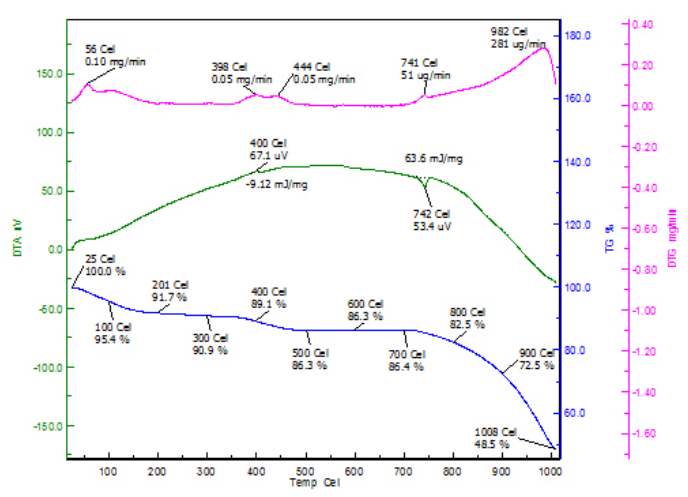

Fig. 4: TGA curve of antimony(III) molybdoarsenate

\section{CONCLUSION}

Newly, synthesized cation-exchanger are now the established material in analytical chemistry useful in separation technique. Antimony(III) molybdoarsenate is good ion-exchange capacity and is stable up to a fairly high temperature, and fairly stable in different acidic, basic and organic media. these ion-exchanger possesses selectivity for trace metals such as, $\mathrm{Pb}, \mathrm{Cd}, \mathrm{Ni}, \mathrm{Co}, \mathrm{Cu}$. Synthetic ion-exchanger are also employed for the binary separation of heavy metals present in aqueous solution.

\section{REFERENCES}

1. Subhash Chand, Seema, Teena and Manju, International Transactions in Applied Sciences, 2010, 2 (1), 181-190

2. Bhawna A., Shah, Ajay V., Shah and Pathik M., Shah, Iranian Polymer Journal,2000,15 (10),809-819.

3. Virendra Kumar, Shuka I.C., Yadav O.P., J. Indian Chem. Soci.,2015, 91, 825-829.

4. Ismail A. A., Mohamed R.M., Ibrahim I.A., Kini G., and Koopman B., Colloids and Surfaces A: Physicochemical and Engineering Aspects, 2010,366(1-3), 80-87.

5. Syed Ashfaq Nabi, Amjad M.T., Khan, Indian Journal of Chemistry,2005,44(A), 13831387.

6. Reetha C, Aravindakshan and Janardanan C, Indian Journal of Chemical,2002, 41(A),
1438-1440.

7. Subhash Chand, Teena, Manju, International Transactions in Applied Sciences,2013, 5 (4), 467-478.

8. Varshney K.G., Agarwal K, Agarwal S, Saxena V, Khan A.R., Colloids and Surface,1988, 29, 175.

9. Qureshi M., Shakeel N A., Rizvi S N A., Gupta A P., Journal of Indian Chemical Society, 1987,64,15.

10. Gupta A P., Verma G L., Saiqa Ikram, Reactive and Functional Polymers,2000, 43, 33-41.

11. Dhara S., Sarkar S., Basu S., Chattopadhyay P., 2009, 67 (4), 530-534.

12. Geetha, Janardhan C., Indian Journal of Chemical Technology,2006, 13, 185-188.

13. Topp N E. and Pepper K W., Journal Chemical 
society,1949,3299.

14. Qureshi M, Varshney K G., and Israeli A H J., Chromatography,1972, 50,141.

15. Virendra Kumar, Shukla I.C., Asian Jouranl of Chemistry,2017, 29, 559-564.

16. Teena, Subhash Chand and Sonia, International Journal of Basic and Applied
Chemical Sciences 2015, 5 (2), 29-39.

17. Nabi S A, Usmaris and Rahman N., Ann. Chim. Fr.1996, 21,521.

18. Aditya K. Mishra, Journal of Chemical Technology,2000, 132-136.

19. Alpana H. Parikh, Uma V. Chudasama, Indian Journal of Chemistry,2003,42, 559-563. 